\title{
PENGARUH BUDAYA ORGANISASI, MOTIVASI KERJA, DAN KEPEMIMPINAN TRANSFORMASIONAL TERHADAP KOMITMEN ORGANISASIONAL
}

\author{
I Gede Utarayana ${ }^{1}$ \\ I Gusti Ayu Dewi Adnyani ${ }^{2}$ \\ ${ }^{1,2}$ Fakultas Ekonomi dan Bisnis Universitas Udayana (Unud), Bali, Indonesia \\ email: igedeutarayana@gmail.com
}

\begin{abstract}
ABSTRAK
Komitmen organisasional adalah suatu keadaan dimana seorang pegawai memihak organisasi tertentu serta tujuan dan keinginan untuk mempertahankan keanggotaan dalam organisasi. Budaya organisasi yang kurang baik, kurangnya motivasi kerja serta gaya kepemimpinan transformasional yang kurang tepat akan mempengaruhi komitmen organisasional. Tujuan penelitian ini adalah mengetahui pengaruh budaya organisasi, motivasi kerja dan kepemimpinan transformasional terhadap komitmen organisasional. Penelitian dilakukan di Sekretariat Daerah Kota Denpasar dengan sampel sebanyak 51 orang pegawai kontrak dengan metode purposive sampling. Pengumpulan data dilakukan dengan penyebaran kuesioner. Berdasarkan hasil analisis, ditemukan bahwa budaya organisasi, motivasi kerja dan kepemimpinan transformasional secara simultan berpengaruh signifikan terhadap komitmen organisasional. Secara parsial budaya organisasi berpengaruh positif terhadap komitmen organisasional, motivasi kerja berpengaruh positif terhadap komitmen organisasional dan kepemimpinan transformasional berpengaruh positif terhadap komitmen organisasional

Kata kunci : Budaya Organisasi, Motivasi Kerja, Kepemimpinan Transformasional dan Komitmen Organisasional
\end{abstract}

\begin{abstract}
Organizational commitment is situation where an employee sided with particular organization, with purpose and desire to maintain membership in the organization. Poor organizational culture, lack of work motivation and transformational leadership styles that are less appropriate will affect organizational commitment. The purpose of this study was to determine effect of organizational culture, work motivation and transformational leadership on organizational commitment. The study was conducted at Regional Secretariat of Denpasar with sample of 51 employees with purposive sampling method. Data collected using questionnaires. Based on the results, organizational culture, work motivation and transformational leadership simultaneously had significant effect on the organizational commitment. Partially organizational culture has a positive effect on the organizational commitment, work motivation has a positive effect on the organizational commitment and transformational leadership has a positive effect on the organizational commitment

Keywords: Organizational Culture, Work Motivation, Transformational Leadership and Organizational Commitment
\end{abstract}




\section{PENDAHULUAN}

Sumber daya manusia memiliki keunggulan yang kompetitif jika dilihat dari keunikan yang dimiliki. Hal itu merupakan pendukung misi dari sebuah organisasi. Terdapat beberapa faktor yang mempengaruhi kualitas sumber daya manusia didalam organisasi. Beberapa faktor ini secara langsung maupun tidak langsung berkaitan dengan budaya serta tipe kepemimpinan organisasional. Pada suatu organisasi komitmen pegawai sebagai faktor pendukung keberhasilan kinerja suatu organisasi sangat penting. Terdapat beberapa faktor yang mempengaruhi komitmen organisasional seperti meningkatnya persaingan dan kelangkaan sumber daya, serta pendekatan yang lebih strategis oleh manajer dan pemimpin organisasi yang bertugas untuk memberikan kepuasan pegawai serta meningkatkan komitmen dan motivasi mereka didalam sebuah organisasi (Eskiler et al., 2016)

Organisasi merupakan sistem sosial dimana sumber daya manusia merupakan faktor yang paling penting untuk efektivitas dan efisiensi. Organisasi memerlukan manajer dan pegawai yang efektif untuk mencapai tujuan mereka (Rizi et al., 2014). Studi telah menemukan berbagai prediktor komitmen organisasional termasuk karakteristik pribadi, pengalaman kerja, karakteristik pekerjaan, status peran, hubungan kelompok/pemimpin, perilaku kepemimpinan, dan karakteristik organisasi (Joo et al., 2013). Komitmen organisasional merupakan salah satu pokok kegiatan serta salah satu tujuan utama dalam upaya organisasi untuk mempertahankan eksistensinya (Hidayat, 2013). Komitmen pegawai dalam perusahaan sangatlah penting karena komitmen pegawai akan berdampak positif terhadap sikap dan perilaku pegawai dalam mencapai tujuan perusahaan (Sidharta \& Margaretha, 2011)

Tingginya komitmen organisasional pegawai dapat dipengaruhi oleh beberapa faktor, salah satunya adalah budaya organisasi seperti yang dinyatakan oleh Lauture et al. (2012), bahwa persepsi positif dari budaya organisasi akan meningkatkan komitmen pegawai. Hsiao et al. (2012), menemukan bahwa budaya organisasi memberikan pengaruh positif pada komitmen organisasional. Yavuz (2012) juga menyatakan bahwa dengan memperkuat budaya organisasi adalah salah satu langkah penting yang akan meningkatkan komitmen organisasional.

Awadh \& Alyahya (2014) mengatakan budaya organisasi merupakan campuran nilai, keyakinan, komunikasi, dan penjelasan perilaku yang memberikan panduan kepada orang-orang. Abdullah \& Arisanti (2010) menyatakan bahwa budaya organisasi adalah suatu tatanan keyakinan yang dianut oleh anggota organisasi, yang berdampak kepada cara bekerja dan perilaku para anggota organisasi. Azeem (2010) juga menyatakan budaya organisasi adalah seperangkat nilai-nilai bersama, keyakinan, dan norma yang mempengaruhi cara karyawan berpikir, merasa, dan berperilaku di tempat kerja.

Budaya yang ada di suatu organisasi sangat besar pengaruhnya terhadap pembentukan pribadi seseorang karena budaya organisasi menyokong tumbuhnya kreativitas sehingga menumbuhkan perilaku inovatif dari anggota organisasional tersebut (Parashakti dkk., 2016). Untuk menciptakan budaya yang dimaksud, perlu dipahami tentang budaya dan bagaimana budaya bekerja. Budaya organisasi mempengaruhi setiap aspek organisasi dan mempengaruhi berbagai outcomes seperti produktivitas, kinerja, komitmen, kepercayaan diri, dan perilaku etis. 
Budaya organisasi adalah variabel yang sangat penting bagi setiap organisasi untuk membangun perilaku yang inovatif, dimana perilaku kerja yang positif dalam bentuk inovasi menjadi bagian yang penting untuk mempersiapkan kemampuan daya saing (Prayudhayanti, 2014). Selain budaya organisasi, motivasi kerja adalah salah satu faktor yang mempengaruhi komitmen organisasional.

Motivasi yang ada pada seseorang merupakan kekuatan pendorong yang akan membuat suatu perilaku guna mencapai tujuan kepuasan dirinya. Organisasi harus mampu memotivasi pegawai agar menguasai pekerjaan dengan baik sesuai arahan supervisi dengan berorientasi pada hasil yang dicapai nantinya. Walumba \& Lawyer (2013) menyatakan bahwa motivasi menjadi alat dan faktor yang mempengaruhi komitmen organisasional. Motivasi adalah keinginan seseorang untuk melakukan suatu tindakan untuk mencapai tujuan yang dorongannya berasal dari orang itu sendiri.(Meysam \& Neyshabor, 2014)

Mitchell (1982), mendefinisikan motivasi sebagai tingkat dimana individu ingin dan memilih untuk terlibat dalam perilaku tertentu yang telah ditetapkan. Peneliti lain menghubungkan konsep motivasi dengan tempat kerja. Chaundary (2015) menyatakan bahwa motivasi adalah proses yang mengarahkan seseorang untuk melakukan sesuatu dalam rangka mencapai tujuan yang telah ditetapkan. Motivasi kerja merupakan daya pendorong yang mengarahkan pegawai untuk bekerja lebih baik dan meningkatkan prestasi kerja (Masoud, 2013).

Pemimpin yang memberikan motivasi kerja kepada bawahan dapat memberikan kekuatan terhadap aktivitas-aktivitas dan mengarahkan tingkah laku bawahan serta dapat membantu mengarahkan karyawan pada sasaran yang ingin dicapai. Antonio \& Sutanto (2014), menyatakan bahwa motivasi kerja dapat ditunjukan dengan perilaku pekerja. Perilaku pegawai yang menunjukkan semangat kerja dapat membuat pegawai bekerja secara maksimal. Tidak hanya pegawai, pemimpin juga memiliki peran penting dalam sebuah organisasi yang ditunjukkan dari gaya kepemimpinannya.

Gaya kepemimpinan diidentifikasi sebagai subjek penting di bidang perilaku organisasi. Pemimpin seharusnya mampu dalam mengarahkan pegawai untuk menjadi lebih baik dalam kinerjanya, dan mampu mengembangkan ide-ide baru yang memungkinkan organisasi untuk tumbuh kompetitif dan menyesuaikan diri dengan perubahan. Seorang pemimpin yang handal adalah orang yang mampu melaksanakan fungsi-fungsi manajemen secara baik dan saling berkaitan, pemimpin memiliki tanggung jawab besar terhadap organisasi yang dipimpinnya.

Menurut Surbakti (2013), seorang pemimpin yang menerapkan gaya kepemimpinan transformasional ditandai dengan besar atau kecilnya pengaruh yang diberikan kepada karyawannya untuk berubah. Seorang pemimpin harus mampu memimpin dan meningkatkan komitmen karyawannya karena aset yang paling penting dalam perusahaan adalah karyawan (Voon et al., 2011). Pemimpin yang memiliki sifat pemimpin transformasional dapat memperkuat komitmen organisasi dengan cara menginspirasi dan memberikan motivasi kepada karyawannya sehingga menjadi lebih berprestasi dalam pekerjaan (Permatasari \& Supartha, 2017).

Hasil Penelitian yang dilakukan oleh Avolio et al. (2014) menunjukan bahwa antara gaya kepemimpinan transformasional dan komitmen organisasional 
memiliki hubungan yang positif. Hasil penelitian yang dilakukan oleh Dunn et al. (2012) juga memberikan bukti yang mendukung bahwa gaya kepemimpinan transformasional secara signifikan dan positif berhubungan dengan komitmen organisasional.

Gaya kepemimpinan transformasional merupakan suatu perilaku pemimpin yang memberikan perhatian kepada karyawannya, rangsangan intelektual serta nilai moral kepada para bawahannya untuk meningkatkan kesadaran individu (Rorimpandey, 2013). Menjadi pemimpin bukan hal mudah, terkadang memimpin secara keras dan ketat adalah cara paling efektif, tapi ada kalanya karyawan justru akan lebih unggul bila dipimpin dengan santai dan fleksibel. Fondasi dari kepemimpinan yang efektif adalah berpikir berdasarkan misi organisasi, mendefinisikannya dan menegakkannya, secara jelas dan nyata. Pemimpin yang baik bisa memberikan contoh yang baik bagi para bawahannya dalam melakukan semua pekerjaannya yang dimana diharapkan bisa meningkatkan komitmen organisasional pegawainya.

Sekretariat Daerah Kota Denpasar merupakan instansi pemerintah yang beralamat di Jalan Gajah Mada No. 1 Denpasar. Pada Sekretariat Daerah Kota Denpasar terdiri atas 10 Bagian, antara lain Bagian Hukum dan HAM, Bagian Organisasi, Bagian Ekonomi, Bagian Humas dan Protokol, Bagian Pengadaan Barang dan Jasa, Bagian Tata Pemerintahan dan Otonomi Daerah, Bagian Umum, Bagian Kerjasama, Bagian Kesejahteraan Rakyat, dan Bagian Administrasi Pembangunan. Pegawai pada Sekretariat Daerah Kota Denpasar tidak hanya terdiri dari PNS saja melainkan terdapat Pegawai Kontrak yang berjumlah 106 orang.

Berdasarkan hasil observasi yang telah dilakukan pada 10 Pegawai Kontrak Sekretariat Daerah Kota Denpasar terlihat bahwa dari 10 responden terdapat 8 responden yang menyatakan tidak bersedia untuk berupaya lebih keras dalam mencapai tujuan organisasi. Masalah-masalah yang terjadi pada perusahaan tersebut muncul akibat dari karakteristik yang dimiliki oleh masing-masing individu berbeda seperti budaya organisasi setiap individu yang berbeda-beda, motivasi kerjanya yang rendah, serta ketidakmampuan pemimpin untuk memberikan dorongan kepada karyawan agar lebih bersemangat dalam bekerja dan kurangnya pengawasan dari pemimpin terhadap pekerjaan yang dilakukan oleh para karyawan. Peranan pemimpin sangat diperlukan dalam perusahaan untuk mendorong karyawan dalam meningkatkan komitmen organisasionalnya. Berdasarkan fenomena yang terjadi maka dicoba untuk mengangkat kembali permasalahan tersebut untuk dijadikan kajian dalam membuktikan bagaimana pengaruh budaya organisasi, motivasi kerja, dan kepemimpinan transformasional terhadap komitmen organisasional pada Sekretariat Daerah Kota Denpasar.

Berdasarkan latar belakang masalah tersebut, maka rumusan masalah dalam penelitian di atas adalah 1) Apakah budaya organisasi berpengaruh terhadap komitmen organisasional pegawai kontrak Sekretariat Daerah Kota Denpasar? 2) Apakah motivasi kerja berpengaruh terhadap komitmen organisasional pegawai kontrak Sekretariat Daerah Kota Denpasar? 3) Apakah kepemimpinan transformasional berpengaruh terhadap komitmen organisasional pegawai kontrak Sekretariat Daerah Kota Denpasar? 
Berdasarkan rumusan masalah yang telah diuraikan, maka tujuan dalam penelitian di atas adalah 1) Untuk menganalisis pengaruh budaya organisasi terhadap komitmen organisasional pegawai kontrak Sekretariat Daerah Kota Denpasar. 2)Untuk menganalisis pengaruh motivasi kerja terhadap komitmen organisasional pegawai kontrak Sekretariat Daerah Kota Denpasar. 3) Untuk menganalisis pengaruh kepemimpinan transformasional terhadap komitmen organisasional pegawai kontrak Sekretariat Daerah Kota Denpasar.

Secara teoritis diharapkan penelitian ini diharapkan dapat mengkonfirmasi tentang Pengaruh Budaya organisasi terhadap Komitmen Organisasional, Pengaruh Motivasi Kerja terhadap Komitmen Organisasional, dan Pengaruh Kepemimpinan Transformasional terhadap Komitmen Organisasional.

Penelitian ini diharapkan menjadi refrensi bagi perusahaan sebagai bahan pertimbangan dan masukan mengenai Pengaruh Budaya organisasi terhadap Komitmen Organisasional, Pengaruh Motivasi Kerja terhadap Komitmen Organisasional, dan Pengaruh Kepemimpinan Transformasional terhadap Komitmen Organisasional. Diharapkan penelitian ini dapat menyumbangkan pemikiran bagi perusahaan dalam menentukan kebijakan khususnya dalam strategi pengelolaan sumber daya manusia.

Lauture et al. (2012) menyatakan terdapat pengaruh yang positif antara variabel budaya organisasi terhadap komitmen organisasional. Hsiao et al. (2012), menemukan bahwa budaya organisasi memberikan pengaruh positif pada komitmen organisasional. Yavuz (2012), juga menyatakan bahwa dengan memperkuat budaya organisasi adalah salah satu langkah penting yang akan meningkatkan komitmen organisasional.

$\mathrm{H}_{1}$ : Budaya organisasi berpengaruh positif terhadap komitmen organisasional

Motivasi menjadi alat dan faktor yang mempengaruhi komitmen organisasional. Pegawai yang memiliki motivasi tinggi akan memiliki komitmen organisasional yang tinggi pula terhadap perusahaan. Abrivianto dkk. (2014) menemukan bahwa motivasi berpengaruh positif terhadap komitmen organisasional.

$\mathrm{H}_{2}$ : Motivasi kerja berpengaruh positif terhadap komitmen organisasional

Pemimpin yang memiliki sifat pemimpin transformasional dapat memperkuat komitmen organisasi dengan cara menginspirasi dan memberikan motivasi kepada karyawannya sehingga menjadi lebih berprestasi dalam pekerjaan (Permatasari \& Supartha, 2017). Hasil Penelitian yang dilakukan oleh Avolio et al. (2014) menunjukan bahwa antara kepemimpinan transformasional dan komitmen organisasional memiliki hubungan yang positif. Hasil penelitian yang dilakukan oleh Dunn et al. (2012) juga memberikan bukti yang mendukung bahwa perilaku pemimpin transformasional secara signifikan dan positif berhubungan dengan komitmen organisasional.

$\mathrm{H}_{3}$ : Kepemimpinan tranformasional berpengaruh positif terhadap komitmen organisasional.

Untuk mempermudah memahami gambaran dan arah penelitian tentang pengaruh antar variabel dalam penelitian maka dapat digambarkan suatu jalur pemikiran yang diterjemahkan dalam kerangka konseptual penelitian sebagai berikut: 


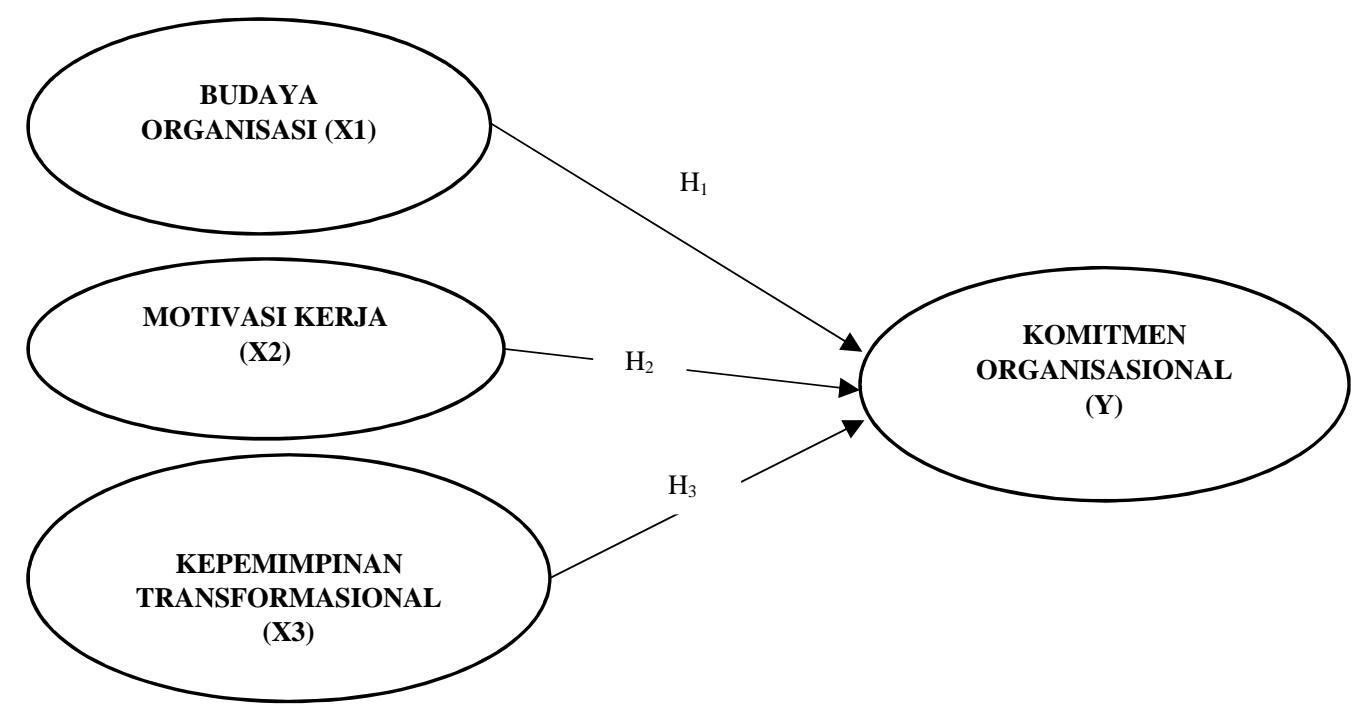

Gambar 1. Konseptual Penelitian

\section{METODE PENELITIAN}

Penelitian ini dilakukan dengan menggunakan pendekatan kuantitatif yang berbentuk asosiatif. Penggunaan metode ini untuk menganalisis Pengaruh Budaya organisasi terhadap Komitmen Organisasional, Pengaruh Motivasi Kerja terhadap Komitmen Organisasional, dan Pengaruh Kepemimpinan Transformasional terhadap Komitmen Organisasional Pegawai Kontrak Sekretariat Daerah Kota Denpasar.

Lokasi diadakannya penelitian ini adalah di Sekretariat Daerah Kota Denpasar. Pemilihan lokasi ini didasarkan atas kurangnya komitmen organisasional di perusahaan yang dimana penelitian ini didukung oleh 3 variabel bebas seperti Budaya Organisasi, Motivasi Kerja, dan Kepemimpinan Transformasional.

Obyek dalam penelitian ini adalah budaya organisasi, motivasi kerja, dan kepemimpinan transformasional. Variabel bebas dalam penelitian ini adalah Budaya Organisasi $\left(\mathrm{X}_{1}\right)$, Motivasi Kerja $\left(\mathrm{X}_{2}\right)$ dan Kepemimpinan Transformasional $\left(\mathrm{X}_{3}\right)$ sedangkan variabel terikat dalam penelitian ini adalah Komitmen Organisasional (Y).

Data merupakan data yang berupa angka/numerik. Data kuantitatif yang digunakan pada penelitian adalah jumlah pegawaidan data yang langsung didapat dari pegawaidengan penyebaran kuesioner Data Kualitatif yang digunakan pada penelitian ini adalah sejarah singkat organisasional, struktur dan uraian tugas. Instrumen penelitian yang digunakan pada penelitian ini adalah kuesioner dengan menggunakan skala Likert

Populasi dalam penelitian ini adalah seluruh pegawai kontrak Sekretariat Daerah Kota Denpasar yang berjumlah 106 orang. Teknik sampel yang akan digunakan pada penelitian ini adalah Purposive Sampling. Kriteria pegawai kontrak yang akan di teliti adalah yang sudah bekerja minimal 2 Tahun di Sekretariat Daerah Kota Denpasar sehingga jumlah sampel yang digunakan adalah 51 responden. Metode pengumpulan data pada penelitian ini menggunakan beberapa metode, yaitu observasi dan survey 


\section{HASIL DAN PEMBAHASAN}

Sekretariat Daerah Kota Denpasar berada di Jalan Gajah Mada No.1 Denpasar, Bali. Terdiri dari 10 Bagian diantaranya, Bagian Hukum dan HAM, Kesra, Humas dan Protokol, Pemerintahan dan Otonomi Daerah, Administrasi Pembangunan, Organisasi, Kerjasama, Umum, Pengadaan Barang dan Jasa, serta Perekonomian.

Adapun Visi dan Misi Sekretariat Daerah Kota Denpasar yaitu terdepan dalam mendorong terwujudnya pemerintahan yang baik (Good Governance) didukung perumusan kebijakan, koordinasi penyelenggaraan pemerintahan dan pembangunan yang semakin handal dan profesional guna mendukung terciptanya Kota Denpasar yang berwawasan budaya. Sedangkan misinya adalah Mewujudkan penyelenggaraan pemerintahan yang menjunjung tinggi supremasi hukum, transparasi, akuntabel, aspiratif, efektif dan efisien.

Data karakteristik responden adalah data responden yang dikumpulkan untuk mengetahui profil responden penelitian. Berdasarkan hasil penelitian yang dilakukan terhadap pegawai kontrak Sekretariat Daerah Kota Denpasar dapat dijelaskan karakteristik responden meliputi jenis kelamin, usia, pendidikan terakhir, lama kerja yang terlihat pada Tabel 1 .

Tabel 1.

Karakteristik Responden

\begin{tabular}{|c|c|c|c|c|}
\hline No & Variabel & Klasifikasi & Jumlah & Persentase (\%) \\
\hline \multirow[t]{3}{*}{1} & Jenis kelamin & Pria & 29 & 56,86 \\
\hline & & Wanita & 22 & 43,14 \\
\hline & Jumlah & & 51 & 100 \\
\hline \multirow[t]{4}{*}{2} & Usia & 21-24 tahun & 7 & 13,73 \\
\hline & & $25-28$ tahun & 25 & 49,02 \\
\hline & & 29-32 tahun & 19 & 37,25 \\
\hline & Jumlah & & 51 & 100 \\
\hline \multirow[t]{3}{*}{3} & Pendidikan & SMA & 9 & 17,65 \\
\hline & Terakhir & S1 & 42 & 82,35 \\
\hline & Jumlah & & 51 & 100 \\
\hline \multirow[t]{5}{*}{4} & Lama Kerja & $1-2$ tahun & 14 & 27,45 \\
\hline & & $2-3$ tahun & 16 & 31,37 \\
\hline & & 3-4 tahun & 17 & 33,33 \\
\hline & & $4-5$ tahun & 4 & 7,84 \\
\hline & Jumlah & & 51 & 100 \\
\hline
\end{tabular}

Sumber: Data Primer Diolah, 2019

Tabel 1. menunjukan bahwa pegawai kontrak di Sekretariat Daerah Kota Denpasar yang berjenis kelamin laki-laki lebih banyak dengan tingkat persentase yaitu 56,86 persen dibandingkan dengan jumlah pegawai kontrak perempuan dengan tingkat persentase 43,14 persen. Tingkat usia dominan yang bekerja diperusahaan adalah dari usia 25-28 tahun, karena usia tersebut termasuk usia yang tergolong produktif, kreatif dan pekerja keras, sehingga dapat berkontribusi lebih baik untuk instansi pemerintahan.

Dilihat dari pendidikan terakhir pegawai kontrak yang ada di Sekretariat Daerah Kota Denpasar lebih dominan pendidikan tertingginya yaitu S1 yang 
berjumlah 42 orang atau sebesar 82,35 persen. Dan untuk lama kerja para pegawai kontrak Sekretariat Daerah Kota Denpasar dominan bekerja selama 4-5 tahun yaitu berjumlah 17 orang atau sebesar 33,33 persen.

Hasil uji validitas instrumen penelitian disajikan pada Tabel 4.2 yang menunjukan bahwa seluruh indikator dalam variabel budaya organisasi, motivasi kerja, kepemimpinan transformasional, dan komitmen organisasional memiliki nilai Pearson Correlation yang lebih besar dari angka 0,30 sehingga seluruh indikator tersebut dikatakan telah memenuhi syarat validitas data.

Tabel 2.

\section{Hasil Uji Validitas}

\begin{tabular}{lccc}
\hline \multicolumn{1}{c}{ Variabel } & Instrumen & Pearson Correlation & Keterangan \\
\hline Budaya Organisasi $\left(\mathrm{X}_{1}\right)$ & X1.1 & .855 & Valid \\
& X1.2 & .766 & Valid \\
& X1.3 & .870 & Valid \\
& X1.4 & .754 & Valid \\
Motivasi Kerja $\left(\mathrm{X}_{2}\right)$ & X1.5 & .896 & Valid \\
& X2.1 & .920 & Valid \\
& X2.2 & .793 & Valid \\
& X2.3 & .850 & Valid \\
Kepemimpinan & X2.4 & .741 & Valid \\
Transormasional $\left(\mathrm{X}_{3}\right)$ & X3.1 & .781 & Valid \\
& X3.2 & .798 & Valid \\
& X3.3 & .690 & Valid \\
& X3.4 & .694 & Valid \\
& X3.5 & .785 & Valid \\
& X3.6 & .754 & Valid \\
Komitmen Organisasional & X3.7 & .742 & Valid \\
(Y) & Y.1 & .733 & Valid \\
& Y.2 & .777 & Valid \\
& Y.3 & .868 & Valid \\
& Y.4 & .694 & Valid \\
& Y.5 & .709 & Valid \\
& Y.6 & .728 & Valid \\
& Y.7 & .813 & Valid \\
& Y.8 & .788 & Valid \\
& Y.9 & .885 & Valid \\
\hline
\end{tabular}

Sumber: Data Primer Diolah, 2019

Tabel 2. menunjukan bahwa seluruh koefisien korelasi dari indikator variabel penelitian yang diuji nilainya lebih besar dari 0,30 (r >0,3). Dengan demikian hasil tersebut menunjukkan bahwa seluruh indikator penelitian terbukti valid.

Hasil uji reliabilitas instrumen pada penelitian ini disajikan pada Tabel 3 yang menunjukan bahwa keempat instrumen penelitian yaitu budaya organisasi, motivasi kerja, kepemimpinan transformasional, dan komitmen organisasional memiliki koefisien cronbach's al pha yang lebih besar dari angka 0,60 sehingga pernyataan pada kuesioner dapat dikatakan reliabel.

Tabel 3. menunjukan bahwa masing-masing nilai cronbach's al pha pada tiap instrumen penelitian lebih besar dari 0,6 (cronbach's alpha > 0,6). Dengan ini demikian hasil tersebut menunjukan bahwa semua instrumen terbukti reliabel, sehingga dapat digunakan untuk melakukan penelitian. 
Tabel 3.

Hasil Uji Reliabilitas

\begin{tabular}{lcc}
\hline \multicolumn{1}{c}{ Variabel } & Cronbadh'sAlpha & Keterangan \\
\hline Budaya Organisasi $\left(\mathrm{X}_{1}\right)$ & .884 & Reliabel \\
Motivasi Kerja $\left(\mathrm{X}_{2}\right)$ & .847 & Reliabel \\
Kepemimpinan & & \\
Transformasional $\left(\mathrm{X}_{3}\right)$ & .865 & Reliabel \\
Komitmen Organisasional $(\mathrm{Y})$ & .916 & Reliabel \\
\hline Sumber: Data Primer Diolah, 2019 & &
\end{tabular}

Tabel 4.

Deskripsi Jawaban Responden terhadap Komitmen Organisasional

\begin{tabular}{|c|c|c|c|c|c|c|c|c|c|}
\hline \multirow[t]{2}{*}{ No } & \multirow[t]{2}{*}{ Indikator } & \multicolumn{5}{|c|}{ Skor Jawaban } & \multirow{2}{*}{$\begin{array}{c}\text { Jumlah } \\
\text { Skor }\end{array}$} & \multirow{2}{*}{$\begin{array}{l}\text { Rata- } \\
\text { rata }\end{array}$} & \multirow[t]{2}{*}{ Ket } \\
\hline & & 1 & 2 & 3 & 4 & 5 & & & \\
\hline 1 & $\begin{array}{l}\text { Saya senang menghabiskan } \\
\text { waktu kerja dalam } \\
\text { organisasi. }\end{array}$ & 0 & 0 & 16 & 28 & 7 & 195 & 3,82 & Tinggi \\
\hline 2 & $\begin{array}{l}\text { Saya bersedia melakukan } \\
\text { apapun demi organisasi. }\end{array}$ & 0 & 16 & 20 & 14 & 1 & 153 & 3,00 & $\begin{array}{l}\text { Cukup } \\
\text { tinggi }\end{array}$ \\
\hline 3 & $\begin{array}{l}\text { Saya bekerja dalam } \\
\text { organisasi merupakan suatu } \\
\text { kewajiban. }\end{array}$ & 0 & 7 & 16 & 17 & 11 & 185 & 3,63 & Tinggi \\
\hline 4 & $\begin{array}{l}\text { Saya tidak akan merasa } \\
\text { tenang jika meninggalkan } \\
\text { organisasi. }\end{array}$ & 0 & 11 & 13 & 23 & 4 & 173 & 3,39 & $\begin{array}{l}\text { Cukup } \\
\text { Tinggi }\end{array}$ \\
\hline 5 & $\begin{array}{l}\text { Saya sulit mendapatkan } \\
\text { pekerjaan seperti sekarang } \\
\text { dengan penghasilan yang } \\
\text { bagus. }\end{array}$ & 0 & 6 & 23 & 17 & 5 & 174 & 3,41 & Tinggi \\
\hline 6 & $\begin{array}{l}\text { Saya sangat dirugikan jika } \\
\text { keluar dari organisasi. }\end{array}$ & 0 & 4 & 16 & 27 & 4 & 184 & 3,61 & Tinggi \\
\hline 7 & $\begin{array}{l}\text { Saya bersedia untuk terlibat } \\
\text { dalam setiap kegiatan } \\
\text { organisasi. }\end{array}$ & 0 & 7 & 13 & 21 & 10 & 187 & 3,67 & Tinggi \\
\hline 8 & $\begin{array}{l}\text { Organisasi ini sangat layak } \\
\text { mendapatkan kesetiaan dari } \\
\text { saya. }\end{array}$ & 0 & 4 & 14 & 26 & 7 & 189 & 3,71 & Tinggi \\
\hline 9 & $\begin{array}{l}\text { Saya bangga menjadi bagian } \\
\text { dari organisasi. }\end{array}$ & 0 & 3 & 13 & 25 & 10 & 195 & 3,82 & Tinggi \\
\hline & Rata-Rata & & & & & & & 3,56 & \\
\hline
\end{tabular}

Sumber: Data Primer Diolah, 2019

Variabel komitmen organisasional dalam penelitian ini merupakan variabel dependen. Variabel komitmen organisasional yang disimbolkan dengan Y, diukur dengan menggunakan 9 indikator yang ditanggapi menggunakan 5 poin skala Likert. Secara rinci, tanggapan responden dapat dilihat pada Tabel 4.

Tabel 4. menunjukan bahwa rata-rata skor dari 9 pernyataan mengenai komitmen organisasional yaitu 3,56 yang berada dikirasaran 3,41-4,20 yang berarti tinggi. Hal ini berarti bahwa komitmen organisasional di Sekretariat Daerah Kota Denpasar berjalan dengan baik. Distribusi jawaban responden terhadap komitmen organisasional memiliki nilai rata-rata tertinggi sebesar 3,82 pada pernyataan saya 
senang menghabiskan waktu kerja dalam organisasi dan pernyataan saya bangga menjadi bagian dari organisasi. Dan untuk nilai rata-rata terendah sebesar 3,00 pada pernyataan saya bersedia melakukan apapun demi organisasi.

Variabel budaya organisasi dalam penelitian ini merupakan variabel independen. Variabel budaya organisasi yang disimbolkan dengan $\mathrm{X}_{1}$, diukur dengan menggunakan 5 indikator yang ditanggapi menggunakan 5 poin skala Likert. Secara rinci, tanggapan responden dapat dilihat pada Tabel 5.

\section{Tabel 5.}

Deskripsi Jawaban Responden terhadap Budaya Organisasi

\begin{tabular}{|c|c|c|c|c|c|c|c|c|c|}
\hline \multirow[t]{2}{*}{ No } & \multirow[t]{2}{*}{ Indikator } & \multicolumn{5}{|c|}{ Skor Jawaban } & \multirow{2}{*}{$\begin{array}{l}\text { Jumlah } \\
\text { Skor }\end{array}$} & \multirow{2}{*}{$\begin{array}{l}\text { Rata- } \\
\text { rata }\end{array}$} & \multirow[t]{2}{*}{ Ket } \\
\hline & & 1 & 2 & 3 & 4 & 5 & & & \\
\hline 1 & $\begin{array}{l}\text { Saya merasa mencurahkan } \\
\text { seluruh kemampuan untuk } \\
\text { bekerja. }\end{array}$ & 0 & 6 & 10 & 23 & 12 & 194 & 3,80 & Tinggi \\
\hline 2 & $\begin{array}{l}\text { Saya merasa bersikap } \\
\text { terbuka kepada karyawan } \\
\text { lain tentang masalah } \\
\text { pekerjaan. }\end{array}$ & 0 & 1 & 13 & 28 & 9 & 198 & 3,88 & Tinggi \\
\hline 3 & $\begin{array}{l}\text { Rapat dilakukan dengan } \\
\text { tepat waktu. }\end{array}$ & 0 & 3 & 12 & 23 & 13 & 199 & 3,90 & Tinggi \\
\hline 4 & $\begin{array}{l}\text { Tidak terjadi permusuhan } \\
\text { antar departemen }\end{array}$ & 0 & 1 & 9 & 23 & 18 & 211 & 4,14 & Tinggi \\
\hline 5 & $\begin{array}{l}\text { Terdapat kerjasama yang } \\
\text { baik antara karyawan } \\
\text { dengan manajemen. }\end{array}$ & 0 & 7 & 9 & 21 & 14 & 195 & 3,82 & Tinggi \\
\hline & Rata-Rata & & & & & & & 3,91 & \\
\hline
\end{tabular}

Sumber: Data Primer Diolah, 2019

Tabel 5. menunjukan bahwa rata-rata skor dari 5 pernyataan mengenai budaya organisasi yaitu 3,91 yang berada dikirasaran 3,41-4,20 yang berarti tinggi. Hal ini berarti bahwa budaya organisasi di Sekretariat Daerah Kota Denpasar berjalan dengan baik. Distribusi jawaban responden terhadap budaya organisasi memiliki nilai rata-rata tertinggi sebesar 4,14 pada pernyataan tidak terjadi permusuhan antar departemen dan untuk nilai rata-rata terendah sebesar 3,80 pada pernyataan saya merasa mencurahkan seluruh kemampuan untuk bekerja.

Variabel motivasi kerja dalam penelitian ini merupakan variabel independen. Variabel motivasi kerja yang disimbolkan dengan X2, diukur dengan menggunakan 4 indikator yang ditanggapi menggunakan 5 poin skala Likert. Secara rinci, tanggapan responden dapat dilihat pada Tabel 6.

Tabel 5. menunjukan bahwa rata-rata skor dari 4 pernyataan mengenai motivasi kerja yaitu 3,83 yang berada dikirasaran 3,41-4,20 yang berarti tinggi. Hal ini berarti bahwa motivasi kerja di Sekretariat Daerah Kota Denpasar berjalan dengan baik. Distribusi jawaban responden terhadap motivasi kerja memiliki nilai rata-rata tertinggi sebesar 4,20 pada pernyataan minat saya tinggi dalam mengerjakan tugas dan untuk nilai rata-rata terendah sebesar 3,67 pada pernyataan saya selalu siap diberikan tugas oleh atasan. 
Tabel 6.

Deskripsi Jawaban Responden terhadap Motivasi Kerja

\begin{tabular}{|c|c|c|c|c|c|c|c|c|c|}
\hline \multirow[t]{2}{*}{ No } & \multirow[t]{2}{*}{ Indikator } & \multicolumn{5}{|c|}{ Skor Jawaban } & \multirow{2}{*}{$\begin{array}{l}\text { Jumlah } \\
\text { Skor }\end{array}$} & \multirow{2}{*}{$\begin{array}{l}\text { Rata- } \\
\text { rata }\end{array}$} & \multirow[t]{2}{*}{ Ket } \\
\hline & & 1 & 2 & 3 & 4 & 5 & & & \\
\hline 1 & $\begin{array}{l}\text { Minat saya tinggi dalam } \\
\text { mengerjakan tugas. }\end{array}$ & 0 & 0 & 9 & 23 & 19 & 214 & 4,20 & Tinggi \\
\hline 2 & $\begin{array}{l}\text { Saya selalu siap diberikan } \\
\text { tugas oleh atasan. }\end{array}$ & 0 & 4 & 12 & 32 & 3 & 187 & 3,67 & Tinggi \\
\hline 3 & $\begin{array}{l}\text { Saya puas dengan pekerjaan } \\
\text { saya. }\end{array}$ & 0 & 2 & 15 & 28 & 6 & 191 & 3,75 & Tinggi \\
\hline 4 & $\begin{array}{l}\text { Saya merasa lingkungan } \\
\text { kerja saya sudah baik. }\end{array}$ & 0 & 0 & 18 & 30 & 3 & 189 & 3,71 & Tinggi \\
\hline & Rata-Rata & & & & & & & 3,83 & \\
\hline
\end{tabular}

Sumber: Data Primer Diolah, 2019

Tabel 7.

Deskripsi Jawaban Responden terhadap Kepemimpinan Transformasional

\begin{tabular}{|c|c|c|c|c|c|c|c|c|c|}
\hline \multirow[t]{2}{*}{ No } & \multirow[t]{2}{*}{ Indikator } & \multicolumn{5}{|c|}{ Skor Jawaban } & \multirow{2}{*}{$\begin{array}{l}\text { Jumlah } \\
\text { Skor }\end{array}$} & \multirow{2}{*}{$\begin{array}{l}\text { Rata- } \\
\text { rata }\end{array}$} & \multirow[t]{2}{*}{ Ket } \\
\hline & & 1 & 2 & 3 & 4 & 5 & & & \\
\hline 1 & $\begin{array}{l}\text { Pemimpin } \\
\text { menyampaikan visi perusahaan } \\
\text { pada bawahannya }\end{array}$ & 0 & 2 & 17 & 31 & 1 & 184 & 3,61 & Tinggi \\
\hline 2 & $\begin{array}{l}\text { Pemimpin mampu membuat } \\
\text { bawahannya bangga karena } \\
\text { memiliki pendirian yang kuat } \\
\text { dalam memimpin perusahaan }\end{array}$ & 0 & 3 & 15 & 27 & 6 & 189 & 3,71 & Tinggi \\
\hline 3 & $\begin{array}{l}\text { Pemimpin mampu memberikan } \\
\text { dorongan kepada karyawan agar } \\
\text { semangat dalam bekerja }\end{array}$ & 0 & 3 & 17 & 26 & 5 & 186 & 3,65 & Tinggi \\
\hline 4 & $\begin{array}{l}\text { Pemimpin mampu untuk dapat } \\
\text { merangsang inovasi dan } \\
\text { kreatifitas bawahan dalam } \\
\text { melakukan pekerjaan. }\end{array}$ & 0 & 4 & 8 & 35 & 4 & 192 & 3,76 & Tinggi \\
\hline 5 & 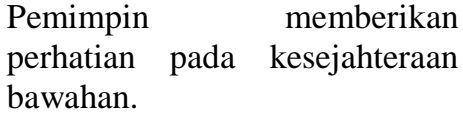 & 0 & 7 & 19 & 22 & 3 & 174 & 3,41 & Tinggi \\
\hline 6 & $\begin{array}{l}\text { Pemimpin mampu melatih } \\
\text { bawahannya }\end{array}$ & 0 & 6 & 19 & 22 & 4 & 177 & 3,47 & Tinggi \\
\hline 7 & $\begin{array}{l}\text { Pemimpin mampu untuk } \\
\text { memperhatikan kebutuhan } \\
\text { bawahan }\end{array}$ & 0 & 6 & 25 & 17 & 3 & 170 & 3,33 & $\begin{array}{l}\text { Cukup } \\
\text { Tinggi }\end{array}$ \\
\hline & Rata-Rata & & & & & & & 3,56 & \\
\hline
\end{tabular}

Sumber: Data Primer Diolah, 2019

Variabel kepemimpinan transformasional dalam penelitian ini merupakan variabel independen. Variabel kepemimpinan transformasional yang disimbolkan dengan $\mathrm{X}_{3}$, diukur dengan menggunakan 7 indikator yang ditanggapi menggunakan 5 poin skala Likert. Secara rinci, tanggapan responden dapat dilihat pada Tabel 7.

Tabel 7. menunjukan bahwa rata-rata skor dari 7 pernyataan mengenai kepemimpinan transformasional yaitu 3,56 yang berada dikirasaran 3,41-4,20 yang berarti tinggi. Hal ini berarti bahwa kepemimpinan transformasional di Sekretariat Daerah Kota Denpasar berjalan dengan baik. Distribusi jawaban responden 
terhadap motivasi memiliki nilai rata-rata tertinggi sebesar 3,76 pada pernyataan pemimpin mampu untuk dapat merangsang inovasi dan kreatifitas bawahan dalam melakukan pekerjaan dan untuk nilai rata-rata terendah sebesar 3,33 pada pernyataan pemimpin mampu untuk memperhatikan kebutuhan bawahan

Analisis regresi linier berganda digunakan untuk mencari koefisien regresi yang akan menentukan apakah hipotesis yang dibuat akan diterima atau ditolak. Model regresi linier berganda digunakan pada penelitian ini karena dapat menjelaskan pengaruh variabel bebas terhadap variabel terikatnya. Tujuan penelitian ini adalah untuk mengetahui pengaruh Budaya Organisasional $\left(\mathrm{X}_{1}\right)$, Motivasi Kerja $\left(\mathrm{X}_{2}\right)$, dan Kepemimpinan Transformasional $\left(\mathrm{X}_{3}\right)$, terhadap Komitmen Organisasional (Y) di Sekretariat Daerah Kota Denpasar. Adapun hasil pengujian analisis regresi linear berganda dari penelitian ini disajikan pada Tabel 8.

Tabel 8.

Hasil Analisis Regresi Linier Berganda

\begin{tabular}{llrrrrr}
\hline \multicolumn{1}{c}{ Model } & B & $\begin{array}{c}\text { Unstandardized } \\
\text { Coefficients } \\
\text { Std. Error }\end{array}$ & $\begin{array}{c}\text { Standardized } \\
\text { Coefficients } \\
\text { Beta }\end{array}$ & t & Sig. \\
\hline $1 \quad$ (Constant) & -.221 & .374 & & -.592 & .557 \\
& Budaya Org. & .281 & .124 & .309 & 2.257 & .029 \\
Motivasi Krj. & .431 & .152 & .389 & 2.831 & .007 \\
Kep. Trans. & .291 & .126 & .242 & 2.304 & .026 \\
Adjusted R & & & & & .693 \\
Sig. F & & & & & .000 \\
\hline
\end{tabular}

Sumber: Data Primer Diolah, 2019

Hasil analisis pada Tabel 4.8 dapat dibuat persamaan regresi linear berganda sebagai berikut.

$Y=-0,221+0,281 X_{1}+0,431 X_{2}+0,291 X_{3}$

Keterangan.

$\mathrm{Y}=$ Komitmen Organisasional

$\mathrm{a}=$ konstanta

$b_{1}, b_{2}, b_{3}=$ Koefisien Regresi

$\mathrm{X}_{1}=$ Budaya Organisasi

$\mathrm{X}_{2}=$ Motivasi Kerja

$\mathrm{X}_{3}=$ Kepemimpinan Transformasional

Budaya organisasi berpengaruh positif terhadap komitmen organisasional. Nilai $\beta_{1}$ menunjukan bahwa ada pengaruh positif antara budaya organisasi dengan komitmen organisasional sebesar 0,281. Motivasi kerja berpengaruh positif terhadap komitmen organisasional. Nilai $\beta_{2}$ menunjukan bahwa ada pengaruh positif antara motivasi kerja dengan komitmen organisasional sebesar 0,431. Kepemimpinan transformasional berpengaruh positif terhadap komitmen organisasional. Nilai $\beta_{1}$ menunjukan bahwa ada pengaruh positif antara kepemimpinan transformasional dengan komitmen organisasional sebesar 0,291. 
Uji asumsi klasik dilakukan dengan tujuan untuk memastikan hasil yang diperoleh memenuhi asumsi dasar di dalam analisis regresi. Hasil uji asumsi klasik yang dilakukan dalam penelitian ini adalah uji normalitas, uji multikolieritas dan uji heteroskedastisitas.

Uji normalitas bertujuan untuk menguji apakah dalam residual dari model regresi yang dibuat berdistribusi normal ataukah tidak. Uji normalitas pada penelitian ini menggunakan uji Kolmogorov-Smirnov (KS), data berkontribusi normal apabila koefisien Asymp Sig. (2-tailed) lebih besar dari 0,05 ( $\alpha=5$ persen). Hasil pengujian normalitas dari penelitian ini disajikan pada Tabel 9 sebagai berikut.

Tabel 9.

Hasil Uji Normalitas

\begin{tabular}{llr}
\hline & Unstandardized Residual & \\
\hline $\mathrm{N}$ & & 51 \\
Normal Parameters & Mean & .0000000 \\
& Std. Deviation & .33464899 \\
Most Extreme & Absolute & .090 \\
Differences & Positive & .063 \\
& Negative & -.090 \\
Kolmogorov-Smirnov Z & & .646 \\
Asymp.Sig (2-tailed) & & .798 \\
\hline Sumber: Data Primer Diolah, 2019 &
\end{tabular}

Tabel 9. menunjukan bahwa nilai Kolmogorov-Smirnov Z sebesar 0,646 sedangkan nilai Asymp Sig. (2-tailed) sebesar 0,798. Hasil tersebut mengindikasikan bahwa model persamaan regresi tersebut berdistribusi normal karena Asymp Sig. (2-tailed) 0,798 lebih besar dari nilai alpha 0,05.

Uji heteroskedastisitas bertujuan untuk menguji apakah model regresi terjadi ketidaksamaan varians dari residual satu pengamatan ke pengamatan lainnya. Model regresi yang baik, tidak mengandung gejala heteroskedastisitas ataupun mempunyai varian yang homogeny daln bila suatu model regresi mengandung gejala heteroskedastisitas akan memberikan hasil yang menyimpang. Jika tidak ada satupun variabel bebas yang berpengaruh signifikan terhadap nilai absolute residual ataupun nilai signifikansinya diatas 0,05 maka tidak mengandung gejala heteroskedastisitas.

Adapun hasil pengujian heteroskedastisitas dari penelitian ini disajikan pada Tabel 10. sebagai berikut.

Tabel 10.

Hasil Uji Heteroskedastisitas

\begin{tabular}{llrrrrr}
\hline \multirow{2}{*}{ Model } & & \multicolumn{2}{c}{$\begin{array}{c}\text { Unstandardized } \\
\text { Coefficients } \\
\text { Std. Error }\end{array}$} & $\begin{array}{c}\text { Standardized } \\
\text { Coefficients } \\
\text { Beta }\end{array}$ & T & Sig. \\
\hline $1 \quad$ B & (Constant) & .331 & .226 & & 1.469 & .148 \\
& Budaya Org. & .121 & .075 & .398 & 1.609 & .114 \\
Motivasi Krj. & -.119 & .092 & -.323 & -.1 .297 & .201 \\
Kep. Trans. & .024 & .076 & -.061 & -.321 & .750 \\
\hline
\end{tabular}

Sumber: Data Primer Diolah, 2019 
Tabel 10. menunjukan bahwa nilai Sig. dari variabel budaya organisasi sebesar 0,114, motivasi kerja sebesar 0,201 dan kepemimpinan transformasional sebesar 0,750. Nilai tersebut lebih besar dari 0,05 yang berarti tidak terdapat pengaruh antara variabel bebas terhadap absolute residual. Dengan demikian, model yang dibuat tidak mengandung gejala heteroskedastisitas.

Uji multikolinearitas bertujuan untuk menguji apakah model regresi ditemukan adanya korelasi antara variabel bebas. Adanya multikolinearitas dapat dilihat dari tolerance dan nilai variance inflation factor (VIF) dan bila nilai tolerance lebih dari 0,10 atau VIF kurang dari 10, maka dikatakan tidak ada multikolinearitas. Adapun hasil pengujian multikolinearitas dari penelitian ini disajikan pada Tabel 11 sebagai berikut.

Tabel 11.

Hasil Uji Multikolinieritas

\begin{tabular}{rlrrrrrr}
\hline \multicolumn{2}{c}{ Model } & \multicolumn{1}{c}{$\begin{array}{c}\text { Budaya } \\
\text { Org. }\end{array}$} & \multicolumn{1}{c}{$\begin{array}{l}\text { Motivasi } \\
\text { Kerja }\end{array}$} & \multicolumn{1}{l}{$\begin{array}{l}\text { Kep. } \\
\text { Trans. }\end{array}$} & Tolerance & VIF \\
\hline 1 & Correlations & Budaya Org. & 1.000 & .805 & .628 & .328 & 3.046 \\
& & Motivasi Krj. & .805 & 1.000 & .634 & .325 & 3.081 \\
& & Kep. Trans. & .628 & .634 & 1.000 & .559 & 1.790 \\
& & & & & & & \\
\hline
\end{tabular}

Sumber: Data Primer Diolah, 2019

Tabel 11. menunjukan bahwa nilai tolerance dan VIF dari variabel budaya organisasi, motivasi kerja, dan kepemimpinan transformasional. Nilai tersebut menunjukan bahwa nilai tolerance untuk setiap variabel lebih besar dari 0,10 dan nilai VIF lebih kecil dari pada 10 yang berarti model persamaan regresi bebas dari multikolinieritas.

Uji Kelayakan Model (Uji F) bertujuan untuk menguji apakah model yang digunakan dalam penelitian ini layak atau tidak untuk digunakan sebagai alat analisis dalam menguji pengaruh variabel independen pada variabel dependennya. Adapun hasil dari pengujian kelayakan model dalam penelitian ini telah disajikan pada Tabel 8, dapat dilihat bahwa nilai $p$-value (Sig. F) yakni 0,000 lebih kecil dari nilai $\alpha=0,05$. Hal ini menunjukkan bahwa penelitian ini layak untuk digunakan sebagai alat analisis untuk menguji pengaruh variabel independen pada variabel dependen.

Uji statistik t dilakukan untuk mengetahui seberapa jauh pengaruh satu variabel independen secara individual menerangkan variasi variabel dependen. Uji statistik t dilakukan dengan membandingkan hasil nilai signifikansi dengan $\alpha=0,05$

Berdasarkan Tabel 8 diperoleh nilai signifikansi uji t dari variabel budaya organisasi dengan $p$-value sebesar 0,029 lebih kecil dari $\alpha=0,05$ serta nilai koefisien regresi sebesar 0,281 . Hal ini mengindikasikan bahwa budaya organisasi berpengaruh positif dan signifikan terhadap komitmen organisasional, sehingga hipotesis pertama dalam penelitian ini diterima.

Berdasarkan Tabel 8. diperoleh nilai signifikansi uji t dari variabel motivasi kerja dengan $p$-value sebesar 0,007 lebih kecil dari $\alpha=0,05$ serta nilai koefisien regresi sebesar 0,431 . Hal ini mengindikasikan bahwa motivasi kerja berpengaruh 
positif dan signifikan terhadap komitmen organisasional, sehingga hipotesis kedua dalam penelitian ini diterima.

Berdasarkan Tabel 8. diperoleh nilai signifikansi uji $\mathrm{t}$ dari variabel kompensasi dengan $p$-value sebesar 0,026 lebih kecil dari $\alpha=0,05$ serta nilai koefisien regresi sebesar 0,291. Hal ini mengindikasikan bahwa kepemimpinan transformasional berpengaruh positif dan signifikan terhadap komitmen organisasional, sehingga hipotesis ketiga dalam penelitian ini diterima.

Analisis Koefisien Determinasi Berganda digunakan untuk mengukur seberapa jauh kemampuan semua variabel bebas dalam menerangkan variasi dari variabel terikatnya. Dalam penelitian ini koefisien determinasi dilihat memalui nilai Adjusted $\mathrm{R}^{2}$. Adapun nilai dari Adjusted $\mathrm{R}^{2}$ pada penelitian ini telah disajikan pada Tabel 4.8 dapat dilihat bahwa nilai Adjusted $\mathrm{R}^{2}$ sebesar 0,693 dimana memiliki arti bahwa 69,3 persen variasi perubahan komitmen organisasional dapat dijelaskan oleh variabel budaya organisasi, motivasi kerja dan kepemimpinan transformasional. Sedangkan sisanya sebesar 30,7 persen dipengaruhi oleh variabel lain diluar dari model penelitian.

Hasil pengujian hipotesis mengenai pengaruh budaya organisasi terhadap komitmen organisasional memperlihatkan bahwa budaya organisasi berpengaruh positif dan signifikan terhadap komitmen organisasional. Hal ini berarti bahwa apabila budaya organisasi semakin baik maka komitmen organisasional pegawai kontrak di Sekretariat Daerah Kota Denpasar akan meningkat dan sebaliknya, semakin buruk budaya organisasi maka komitmen organisasional yang dimiliki pegawai kontrak di Sekretariat Daerah Kota Denpasar akan menurun.

Hasil penelitian ini sesuai dengan penelitian sebelumnya yang dilakukan oleh Lauture et al. (2012) menyatakan terdapat pengaruh yang positif antara variabel budaya organisasi terhadap komitmen organisasional. Hsiao et al. (2012), menemukan bahwa budaya organisasi memberikan pengaruh positif pada komitmen organisasional. Yavuz (2012) juga menyatakan bahwa dengan memperkuat budaya organisasi adalah salah satu langkah penting yang akan meningkatkan komitmen organisasional. Hal ini berarti semakin baik budaya organisasi maka akan meningkatkan komitmen organisasional, maka ini berarti untuk dapat meningkatkan komitmen organisasional pegawai haruslah memperhatikan betul budaya organisasi perusahaan.

Hasil pengujian hipotesis mengenai pengaruh motivasi kerja terhadap komitmen organisasional memperlihatkan bahwa motivasi kerja berpengaruh positif dan signifikan terhadap komitmen organisasional. Hal ini berarti bahwa apabila motivasi kerja semakin baik maka komitmen organisasional di Sekretariat Daerah Kota Denpasar akan meningkat dan sebaliknya, semakin buruk motivasi kerja maka komitmen organisasional yang dimiliki pegawai kontrak di Sekretariat Daerah Kota Denpasar akan menurun.

Hasil penelitian ini sesuai dengan penelitian sebelumnya yang menjelaskan bahwa motivasi menjadi alat dan faktor yang mempengaruhi komitmen organisasional. Pegawai yang memiliki motivasi tinggi akan memiliki komitmen organisasional yang tinggi pula terhadap perusahaan. Abrivianto dkk. (2014), menemukan bahwa motivasi berpengaruh positif terhadap komitmen organisasional. Hal ini berarti semakin tinggi motivasi kerja maka akan 
meningkatkan komitmen organisasional, maka ini berarti untuk dapat meningkatkan komitmen organisasional haruslah memperhatikan betul motivasi kerja yang diberikan antar rekan kerja atau atasan.

Hasil pengujian hipotesis mengenai pengaruh kepemimpinan transformasional terhadap komitmen organisasional memperlihatkan bahwa kepemimpinan transformasional berpengaruh positif dan signifikan terhadap komitmen organisasional. Hal ini berarti bahwa apabila kepemimpinan transformasional semakin baik maka komitmen organisasional pegawai kontrak di Sekretariat Daerah Kota Denpasar akan meningkat dan sebaliknya, semakin buruk kepemimpinan transformasional maka komitmen organisasional yang dimiliki pegawai kontrak di Sekretariat Daerah Kota Denpasar akan menurun.

Hasil penelitian ini sesuai dengan penelitian sebelumnya yang dilakukan oleh Permatasari \& Supartha (2017) dalam penelitiannya mengemukakan bahwa pemimpin yang memiliki sifat pemimpin transformasional dapat memperkuat komitmen organisasi dengan cara menginspirasi dan memberikan motivasi kepada karyawannya sehingga menjadi lebih berprestasi dalam pekerjaan. Hasil Penelitian yang dilakukan oleh Avolio et al. (2014), menunjukan bahwa antara kepemimpinan transformasional dan komitmen organisasional memiliki hubungan yang positif.

Hasil penelitian yang dilakukan oleh Dunn et al. (2012) juga memberikan bukti yang mendukung bahwa perilaku pemimpin transformasional secara signifikan dan positif berhubungan dengan komitmen organisasional. Hal ini berarti semakin baik kepemimpinan transformasional di perusahaan atau kantor akan membuat dampak yang positif kepada pegawai kontrak yang tentunya akan berdampak besar terhadap komitmen organisasionalnya.

Hasil penelitian ini memiliki implikasi teoritis dan praktis. Secara teoritis hasil penelitian ini menunjukan bahwa budaya organisasi, motivasi kerja dan kepemimpinan transformasional berpengaruh positif dan signifikan terhadap komitmen organisasional. dengan demikian, hasil penelitian ini memberi dukungan empiris dan dapat dinyatakan memperkuat hasil-hasil studi terdahulu.

Secara praktis, berdasarkan hasil penelitian ditemukan bahwa indikator budaya organisasi dengan nilai rata-rata terendah sebesar 3,80 pada indikator Percaya rekan sekerja, ini menunjukan bahwa di Sekretariat Daerah Kota Denpasar perlu meningkatkan kepercayaan antar rekan sekerja untuk menunjang peningkatan komitmen organisasional pegawai. Pada indikator penilaian motivasi kerja pada penelitian ini ditemukan hasil bahwa lingkungan kerja memiliki nilai rata-rata terendah sebesar 3,67 hal ini menunjukan bahwa Sekretariat Daerah Kota Denpasar perlu meningkatkan kondisi lingkungan kerja sehingga akan menunjang komitmen organisasional pegawai dan berdasarkan hasil penelitian bahwa dari indikator pengukuran variabel kepemimpinan transformasional nilai terendah pada indikator pengaruh idealis yaitu sebesar 3,00 hal ini menunjukan bahwa pegawai di Sekretariat Daerah Kota Denpasar merasa kurang bangga terhadap pendirian pemimpin yang kurang kuat dalam memimpin perusahaan. Maka dari hasil penelitian yang dilakukan di Sekretariat Daerah Kota Denpasar hendaknya pihak instansi Sekretariat Daerah Kota Denpasar hendak memperhatikan percaya rekan sekerja, lingkungan kerja, dan pengaruh idealis untuk lebih meningkatkan 
komitmen organisasional Sekretariat Daerah Kota Denpasar sehingga tercipta kerjasama yang baik yang membuat citra instansi menjadi lebih baik.

Penelitian ini yang telah diusulkan dan dilaksanakan sesuai dengan prosedur ilmiah, namun demikian masih memiliki keterbatasan, seperti Penelitian ini hanya bisa dilakukan pada pegawai kontrak Sekretariat Daerah Kota Denpasar yang melibatkan responden dengan jumlah terbatas yaitu 51 responden yang merupakan pegawai kontrak yang bekerja di Sekretariat Daerah Kota Denpasar. Sehingga masih dirasa perlu untuk melakukan penelitian dengan topik yang serupa namun pada lokasi dan jumlah responden yang lebih besar. Penelitian ini hanya meneliti sebatas pada tiga variabel saja yang sesuai dengan judul penelitian. Diharapkan pada penelitian selanjutnya dapat mengembangkan lagi variabel yang diteliti mengingat terdapat banyak variabel-variabel lain yang mempengaruhi komitmen organisasional.

\section{SIMPULAN}

Berdasarkan pembahasan hasil analisis data penelitian dan mengacu pada tujuan penelitian yang sudah diuraikan pada bab pendahuluan, maka simpulan yang dapat disampaikan sekaligus yang dapat digunakan untuk menjawab rumusan masalah penelitian yang diajukan adalah Variabel budaya organisasi secara parsial berpengaruh positif dan signifikan terhadap komitmen organisasional pegawai kontrak di Sekretariat Daerah Kota Denpasar. Variabel motivasi kerja secara parsial berpengaruh positif dan signifikan terhadap komitmen organisasional pegawai kontrak di Sekretariat Daerah Kota Denpasar. Variabel kepemimpinan transformasional secara parsial berpengaruh berpengaruh positif dan signifikan terhadap komitmen organisasional pegawai kontrak di Sekretariat Daerah Kota Denpasar.

Berdasarkan hasil analisis dan simpulan diatas maka dapat diajukan beberapa saran yaitu Pemerintah pusat diharapkan lebih memperhatikan mengenai proses seleksi penerimaan pegawai kontrak agar yang terpilih merupakan orang yang berkompeten dan memiliki tanggung jawab serta dedikasi yang tinggi di bidangnya masing-masing.Pimpinan di masing-masing bagian sebaiknya mampu menanamkan budaya organisasi yang baik kepada pegawai kontrak kemudian memperhatikan faktor yang mampu meningkatkan motivasi kerja pegawai kontrak serta menerapkan gaya kepemimpinan transformasional untuk meningkatkan komitmen organisasional pegawai kontrak di Sekretariat Daerah Kota Denpasar. Pegawai kontrak di masing-masing bagian diharapkan memiliki komitmen organisasional yang tinggi untuk meningkatkan kinerja sehingga mampu

memaksimalkan efisiensi dan efektivitas kerja di Sekretariat Daerah Kota Denpasar.

\section{REFERENSI}

Abdullah, \& Arisanti, H. (2010). Pengaruh Budaya Organisasional, Komitmen Organisasional dan Akuntabilitas Publik terhadap Kinerja Organisasional. Jurnal Ekonomi Dan Bisnis, 9(2), 118-134. 
Abrivianto, P. ., Swasto, B., \& Utami, H. N. (2014). Pengaruh Motivasi Kerja dan Komitmen Organisasionalonal terhadap Karyawan (Studi pada Karyawan Bagian HRD PT Arthawena Sakti Gemilang Malang). Jurnal Administrasi Bisnis (JAB), 7(2), 1-9.

Antonio, N. E., \& Sutanto, E. M. (2014). Pengaruh Motivasi Dan Kepuasan Kerja Karyawan Terhadap Organizational Citizenship Behavior Di CV Supratex. Jurnal Universitas Kristen Petra, 2(1), 121-131.

Avolio, B. ., Zhu, W., \& Bhatia, P. (2014). Transformational Leadership and Organizational Commitment: Mediating Role of Psychological Empowerment and Moderating Role of Structural Distance. Journal of Organizational Behavior, 25(1), 951-968.

Awadh, A. M., \& Alyahya, M. S. (2014). Impact of Organizational Culture on Employee Performance. International JournalManagement and Business Research, 2(1), 168-175.

Azeem, S. M. (2010). Job Satisfaction And Organizational Commitment Among Employees In The Sultane Of Oman. Psychology, 5(2), 295-299.

Chaundary, N. (2015). Impact of Employee Motivation on Performance (Productivity) in Private Organization. International Journal of Business Trends and Technology, 2(4), 46-59.

Dunn, M. W., Dastoor, B., \& Sims, R. L. (2012). Transformational Leadership and Organiational Commitment: A Cross-Cultural Perspective. ... ... Journal of Multidisciplinary Research, 4(1), 25-59.

Eskiler, E., Ekici, S., Soyer, F., \& Sari, I. (2016). The Relationship Between Organizational Culture And Innovative Work Behavior For Sports Services In Tourism Enterprises. Physical Culture \& Sport Studies \& Research, 69(1), 53-64.

Hidayat, R. (2013). Pengaruh Kepemimpinan Terhadap Komunikasi, Kepuasan Kerja, dan Komitmen Organisasional Pada Industri Perbankan. Makara Seri Sosial Humaniora, 17(1), 19-32.

Hsiao, H. C., Chang, C., \& Tu, Y. T. (2012). The Influence Of Hospital Organizational Culture On Organizational Commitment Among Nursing Executives. African Journal of Business Management, 6(44), 10888-10895.

Joo, B. ., Juan, Y. H., \& Jeung, C. . (2013). The Effects Of Core Self-Evaluations And Transformational Leadership On Organizational Commitment. Leadership \& Organization Development Journal, 33(6), 564-582.

Lauture, R., Amewokunu, Y., Lewis, S., Lawson, B., \& Assion. (2012). Impact Of Culture On The Organizational Commitment Of Public-Sector Employees In Haiti. International Business and Economics Research Journal, 11(3), 331342. 
Masoud, G. (2013). The Effect of Organizational Culture, Teamwork and Organizational Development on Organizational Commitment: The Mediating Role of Human Capital. Technical Gazette Journal, 20(6), 1019-1025.

Meysam, A. M., \& Neyshabor, A. J. (2014). Work Motivation and Organizational Commitment Among Iranian Employees. International Journal of Research in Organizational Behaviour and Human Resource Management, 1(3), 1-12.

Parashakti, R. D., Rizki, M., \& Saragih, L. (2016). Pengaruh Kepemimpinan Transformasional dan Budaya Organisasional Terhadap Perilaku Inovatif Karyawan. Jurnal Manajemen Teori Dan Terapan, 9(2), 81-96.

Permatasari, K., \& Supartha, W. (2017). Pengaruh Kepemimpinan Transformasional, Budaya Organisasi, Dan Keadilan Organisasi Terhadap Komitmen Organisasional Pada CV. Megah Food Trading. E-Jurnal Manajemen Universitas Udayana, 6(8), 4127-4155.

Prayudhayanti, B. N. (2014). Peningkatan Perilaku Inovatif Melalui Budaya Organisasional. EKOBIS, 15(2), 19-32.

Rizi, R. M., Azadi, A., Farsani, M. E., \& Aroufzad, S. (2014). Relationship Between Leadership Styles And Job Satisfaction Among Physical Education Organizations Employees. European Journal of Sports and Exercise Science, 2(1), 7-11.

Rorimpandey, L. (2013). Gaya Kepemimpinan Transpormasional, Transaksional Situasional, Pelayanan dan Autentik Terhadap Kinerja Pegawai Keluraha Di Kecamatan Bunaken Kota Manado. Jurnal EMBA, 1(4), 89-90.

Sidharta, N., \& Margaretha, M. (2011). Dampak Komitmen Organisasi dan Kepuasan Kerja terhadap Turnover Intention : Studi Empiris pada Karyawan bagian Operator di salah satu Perusahaan Garmen di Cimahi. Jurnal Manajemen, 10(22), 129-142.

Surbakti. (2013). Analisis Pengaruh Kepemimpinan Transformasional dan Motivasi terhadap Kinerja Karyawan: Studi pada PT. Kereta Api Indonesia Daop IV Semarang. Jurnal Fakultas Ekonomi Unniversitas Diponogoro Semarang, 1(1), 55-67.

Voon, M. L., Lo, M. C., Ngui, K. S., \& Ayob, N. B. (2011). The Influence Of Leadership Styles On Employee Job Satisfaction In Public Sector Organization. International Business \& Economic Research Journal, 2(1), $24-32$.

Walumba, F., \& Lawyer, J. (2013). Building Effective Organizations: Transformational Leadership, Collectivist Orientation, Work-Related Attiudes and Withdrawal Behaviours in Three Emerging Economies. The International Journal of Human Resource Management, 14(7), 1083-1101. 
E-Jurnal Manajemen, Vol. 9, No. 1, 2019 : 344-363

Yavuz, M. (2012). The Effects of Teachers Perception of Organizational Justice and Culture on Organizational Commitment. African Journal OfBusiness Management, 4(5), 695-701. 